\title{
Metastasis Induction
}

National Cancer Institute

\section{Source}

National Cancer Institute. Metastasis Induction. NCI Thesaurus. Code C40757.

Metastasis Induction involves initiation of the spread or migration of cancer cells from one part of the body (the organ in which it first appeared) to another. The secondary tumor contains cells that are like those in the original (primary) tumor. $(\mathrm{NCl})$ 